\title{
The Technology Contribution Analysis on Crude Palm Oil Industry in Jambi Province
}

\author{
Sahrial $^{\# 1}$, Yernisa ${ }^{\# 2}$, Jauharie ${ }^{\# 3}$ \\ \# Agricultural Product Technology Department, Jambi University, Pondok Meja, Muaro Jambi Regency, 36364, Indonesia \\ E-mail: ${ }^{1}$ sahrial@unja.ac.id, ${ }^{2}$ yernisa@unja.ac.id, ${ }^{3}$ jauharierizal@gmail.com
}

\begin{abstract}
The objective of this research was to analysis the technology contribution coefficient (TCC) on crude palm oil industry in Jambi Province. This research was conducted in several steps i.e. determination of the research object, assessment of technology components, analysis of experimental data (tabulation of data, estimation the degree of sophisticated, analysis the state-of-the-art for technology components, calculation of technology component contribution, calculation of contribution intensity), and calculation of technology contribution coefficient (TCC). The research obtained 0,590 TCC value for PT. Sumbertama Nusa Pertiwi Bakrie Sumatra Plantation Tbk. Palm Oil Mill and 0,585 TCC value for PSB II Bunut PT. Perkebunan Nusantara VI (Persero) Palm Oil Mill. The both of values indicated the level of technology in the crude palm oil industry on Jambi Province based on a qualitative assessment of TCC interval are in good classification and based on the level of technology is at the level of semi-modern technology.
\end{abstract}

Keywords - crude-palm-oil-industry, Jambi-Province, technology-component, and technology-contribution

\section{INTRODUCTION}

Palm oil is one of the plantation commodities which have the potential prospects in Indonesia. Sarono et. al (2014) acknowledge that the palm oil industry is an important economic sector in Indonesia, for now and future. Oil palm plantations has been done in nearly all parts of Indonesia, particularly in Sumatra and Kalimantan Island. Palm oil processing is done in palm oil mill (POM). Based on data from Estate Plantation Services of Jambi Province (2013), up to December 2012 in Jambi Province with 45 units POM spread in 7 regency namely Batanghari, Muaro Jambi, Bungo, Tebo, Merangin, Sarolangun, and Tanjabbar Regency, with the highest number of POM are on Muaro Jambi (12 units or equal to $29 \%$ ).

Based on data from the Directorate General of Estate Plantation (2013), Jambi Province CPO production in 2012 reached 1.885 .530 tons. The large number of $\mathrm{CPO}$ production is made Jambi become the third largest palm oil producer in the island of Sumatra, after Riau and North Sumatra. CPO availability in large quantities into the excellent potential of Jambi in developing palm oil processing industry. Excellent potential is a result of endowment factor. According Hafids (2006), industrial products which only use endowment factor, without being able to created factor is predicted to be eliminated, not only in the global market, but also in regional and local markets.
Application of created factors may include the application of the technology is a key factor to forming a competitive advantage on an industrial product (Alkadri et al, 1999). According Kumaraswamy et. al (2004), technology be composed technoware, humanware, infoware and organoware. The technology components required in the process of transforming inputs to outputs in a production operations (Sa'id et al, 2004).

Research on the contribution of technology on crude palm oil industry in the province of Jambi has never been done. Based on these matters need to analyze the contribution of technology to the industrial processing of palm oil (CPO) in Jambi Province. Analysis of the contribution of technology useful to determine the level of technology that includes components technoware, humanware, infoware, and organoware in creating added value in palm oil processing industry (CPO) in Jambi Province.

\section{MATERIALS AND METHODS}

This study uses survey research methods. Technological content analysis carried out on the production of fresh fruit bunches (FFB) to CPO. CPO processing technology level was measured using a model technometric (Nazaruddin, 2008). Technometric model defines the coefficient contribution of technology (TCC). This research was conducted in four steps. 


\section{A. Determination of the research object}

The research was conducted on two existing POM in Muaro Jambi, namely PT. Sumbertama Nusa Pertiwi Bakrie Sumatra Plantation (PT. SNP BSP) POM and PSB II Bunut PT. Nusantara Plantation VI (Persero) (PSB II Bunut PTPN VI) POM. Selection of POM is done by purposive sampling with consideration of the ownership status of the POM (POM with private ownership (PT. SNP BSP) and POM with state ownership (PSB II Bunut PTPN VI).

\section{B. Assessment of technology components}

Assessment of technological component in the process of transformation FFB to $\mathrm{CPO}$ at POM, which includes technoware, humanware, infoware and organoware.

\section{Analysis of experimental data}

a. Tabulation of data

b. Estimation of the degree of sophistication of the technology with the scoring method. The estimation results provide an upper limit (UL) and lower limit (LL) the degree of sophistication of each technology component.

c. Assessment of state of the art for each technology component using the formula:
Technoware: $\quad \mathrm{STi}=1 / 10\left[\sum \mathrm{t}_{\mathrm{ik}} / \mathrm{kt}\right]$
Humanware: $\quad \mathrm{SHj}=1 / 10\left[\sum \mathrm{h}_{\mathrm{ij}} / \mathrm{ih}\right]$
Infoware: $\quad$ SI $=1 / 10\left[\sum \mathrm{fm} / \mathrm{mf}\right]$
Organoware: $\quad \mathrm{SO}=1 / 10\left[\sum \mathrm{on} / \mathrm{no}\right]$

d. The valuation of the contribution of each component, is done by using the value limits the degree of sophistication and value of the state of the art by using the formula:
Technoware: $\quad \mathrm{T}=1 / 9[\mathrm{LT}+\mathrm{STi}(\mathrm{UT}-\mathrm{LT})]$
Humanware: $\quad \mathrm{H}=1 / 9[\mathrm{LH}+\mathrm{SHj}(\mathrm{UH}-\mathrm{LH})]$
Infoware: $\quad \mathrm{I}=1 / 9[\mathrm{LI}+\mathrm{SI}(\mathrm{UI}-\mathrm{LI})]$
Organoware: $\quad \mathrm{O}=1 / 9[\mathrm{LO}+\mathrm{SO}(\mathrm{UO}-\mathrm{LO})]$

e. Determination of the intensity contribution of each component technology using pairwise comparison matrix approach. The purpose of the determination of the intensity contribution of technology component that is to get the value of the interest rate scale technology components $(\beta)$.

\section{Assessment of the contribution of technology}

Assessment of the contribution of technology based on formula technology contribution coefficient:

$$
\mathrm{TCC}=\mathrm{T}^{\beta \mathrm{t}} \cdot \mathrm{H}^{\beta \mathrm{h}} \cdot \mathrm{I}^{\beta \mathrm{i}} \cdot \mathrm{O}^{\beta \mathrm{o}}
$$

TCC values obtained are then compared with the interval qualitative assessment table and the level of technology (Fauzan, 2009), so it can be known classification of technology and the level of technology at POM.

\section{RESULTS AND DISCUSSION}

\section{A. Degree of Sophistication of Technology}

The upper limit and the lower limit level of sophistication of the technology component in FFB production process becomes CPO can be seen in Table 1. In general, the sophistication of the technology components technoware on two POM is in the category of special facilities (4-6) and automatic facilities (5-7) except sorting station for the lower limit manually enter the facility category.

Humanware components on the two POM has degrees of sophistication that vary according to the type of work performed by employees. The highest level of capabilities possessed by managers (Mill Managers, Assistant and Foreman) which has the capability of innovation (score 7-9), developing (score 6-8), adaptation (score 5-7) and operate (score 1-3), whereas for labour employees (laboratory and operators) only has the ability to operate. Technicians at two levels of POM has the ability to reproduce (4-6), repair (3-5) and setting (score 2-4). In addition, technicians also have the ability to adapt and operate.

The level of sophistication infoware at two levels of POM have in common is the level of repair information (score 6-8) for the upper limit and the introduction of information (score 1-3) for the lower limit. As for the level of sophistication organoware components contained in the two POM there is a difference. PT. SNP BSP POM has organoware skill level in the framework of stability (score 5-7), while for the PSB II Bunut PTPN VI POM besides having stability framework, and the framework of the merger (score 2-4).

TABLE I

DEGREE OF SOPHISTICATION OF TECHNOLOGY

\begin{tabular}{|c|c|c|c|c|}
\hline \multirow{3}{*}{$\begin{array}{l}\text { Technology } \\
\text { Component }\end{array}$} & \multicolumn{4}{|c|}{ Degree of sophistication of } \\
\hline & \multicolumn{2}{|c|}{$\begin{array}{l}\text { PT. SNP BSP } \\
\text { POM }\end{array}$} & \multicolumn{2}{|c|}{$\begin{array}{l}\text { PSB II Bunut } \\
\text { PTPN VI POM }\end{array}$} \\
\hline & $\begin{array}{l}\text { Upper } \\
\text { Limit }\end{array}$ & $\begin{array}{c}\text { Lower } \\
\text { Limit }\end{array}$ & $\begin{array}{l}\text { Upper } \\
\text { Limit }\end{array}$ & $\begin{array}{l}\text { Lower } \\
\text { Limit }\end{array}$ \\
\hline \multicolumn{5}{|l|}{ Technoware } \\
\hline Sorting Station & 2 & 4 & 2 & 4 \\
\hline Sterilization Stasion & 5 & 6 & 5 & 6 \\
\hline Thresher Stasion & 5 & 6 & 5 & 6 \\
\hline Press Station & 5 & 7 & 5 & 7 \\
\hline Clarification Station & 5 & 7 & 6 & 7 \\
\hline Storage Station & 5 & 6 & 5 & 6 \\
\hline \multicolumn{5}{|l|}{ Humanware } \\
\hline Mill Manager & 7 & 8 & 7 & 8 \\
\hline Processing Assistant & 3 & 7 & 3 & 7 \\
\hline $\begin{array}{l}\text { Quality Control } \\
\text { Assistant }\end{array}$ & 3 & 7 & 3 & 7 \\
\hline Maintenace Assistant & 3 & 7 & 3 & 7 \\
\hline Foreman & 2 & 6 & 2 & 5 \\
\hline Technicians & 2 & 6 & 2 & 6 \\
\hline Laboratory & 1 & 2 & 1 & 2 \\
\hline Operators & 1 & 3 & 1 & 2 \\
\hline Infoware & 3 & 7 & 3 & 8 \\
\hline Organoware & 5 & 7 & 3 & 7 \\
\hline
\end{tabular}

\section{B. State of The Art Technology Component}

State of the art of each component technology used in the palm oil industry in Jambi Province can be seen in Table 2. The state of the art technology technoware component and organoware component relatively similar between the two POM. This is due to the use of the same equipment and machines for processing FFB become CPO (technoware) 
and the level of use of the device is the same organization that is equally under a large holding company (PT. Bakrie Sumatera Plantations Tbk. and PT. Perkebunan Nusantara VI (Persero)).

There are differences in state of the art for humanware and organoware components on both the POM. Differences in state of the art for humanware component is influenced by educational qualifications and the ability of workers to maintain production facilities, creativity and innovation in completing the problem, the ability to cooperate and awareness, discipline and responsibility of the individual in his work. As for the state of the art components infoware influenced enterprise information networks, information systems supporting enterprise activities, information storage and availability of standard operational procedures as well as the level of quantity of delivery problems, the internal conditions and the latest in information technology employees.

TABLE II

StATE OF THE ART TECHNOLOGY COMPONENT

\begin{tabular}{|l|c|c|}
\hline \multirow{2}{*}{$\begin{array}{c}\text { Technology } \\
\text { Component }\end{array}$} & $\begin{array}{c}\text { State of The Art } \\
\text { POP BSP }\end{array}$ & $\begin{array}{c}\text { PSB II Bunut } \\
\text { PTPN VI POM }\end{array}$ \\
\cline { 2 - 3 } Technoware & \multicolumn{2}{|c|}{} \\
\hline Sorting Station & 0,60 & 0,58 \\
\hline Sterilization Stasion & 0,71 & 0,67 \\
\hline Thresher Stasion & 0,60 & 0,62 \\
\hline Press Station & 0,71 & 0,69 \\
\hline Clarification Station & 0,72 & 0,74 \\
\hline Storage Station & 0,74 & 0,73 \\
\hline Humanware & & \\
\hline Mill Manager & 0,92 & 0,88 \\
\hline Processing Assistant & 0,77 & 0,88 \\
\hline $\begin{array}{l}\text { Quality Control } \\
\text { Assistant }\end{array}$ & 0,88 & 0,87 \\
\hline Maintenace Assistant & 0,82 & 0,88 \\
\hline Foreman & 0,80 & 0,78 \\
\hline Technicians & 0,80 & 0,75 \\
\hline Laboratory & 0,77 & 0,73 \\
\hline Operators & 0,80 & 0,79 \\
\hline Infoware & 0,93 & 0,82 \\
\hline Organoware & 0,78 & 0,75 \\
\hline \multicolumn{2}{|l|}{} \\
\hline
\end{tabular}

\section{Contributions Component Technology}

Results calculated contribution of each component technology can be seen in Table 3. The contribution components of the technology at both POM is the same. Value contributions humanware be the smallest contribution when viewed from the importance of the value of the component in the transformation process FFB to CPO on crude palm oil industry in the Province of Jambi. The cause is due to the small value of human resources at the POM at the level of labour employees (Laboratory and Operator) has a low level of ability that is only limited to operate, but on another level labour employees (engineers) and managers (Mill Manager, Assistant, and Foreman) has had a relatively high level of capability that is at the level of adapting, developing and innovating. The difference in the level of capability that far that causes contribution humanware component becomes smaller than the value of the other contributions.

\section{Intensity Contribution Technology}

Intensity values the contribution of technology components are presented in Table 3. Can be seen, the intensity value of each component according to the experts and practitioners as follows: $\beta$ technoware $>\beta$ humaware $>\beta$ infoware $>\beta$ organoware. Based on the calculation consitensy ratio of 0.1 indicates that the assessment of the level of importance that has consistently performed because the value of $\leqslant 0,1$. The highest intensity for technoware components show that in the process of CPO production in Jambi Province is more dependent on the equipment and machinery that is a major component in the formation of value-added technology in the processing of FFB into CPO. Therefore, improvement of the equipment and machinery is a priority in the development.

TABLE III

CONTRIBUTIONS COMPONENT TECHNOLOGY AND INTENSITY CONTRIBUTION TECHNOLOGY

\begin{tabular}{|c|c|c|c|}
\hline \multirow[b]{2}{*}{$\begin{array}{l}\text { Technology } \\
\text { Component }\end{array}$} & \multicolumn{2}{|c|}{$\begin{array}{l}\text { Contributions } \\
\text { Component }\end{array}$} & \multirow[b]{2}{*}{$\begin{array}{c}\text { Intensity } \\
\text { Contribution } \\
\text { Technology }\end{array}$} \\
\hline & $\begin{array}{l}\text { PT. SNP } \\
\text { BSP POM }\end{array}$ & $\begin{array}{c}\text { PSB II } \\
\text { Bunut } \\
\text { PTPN VI } \\
\text { POM } \\
\end{array}$ & \\
\hline Technoware & 0,613 & 0,616 & 0,512 \\
\hline Humanware & 0,446 & 0,427 & 0,257 \\
\hline Infoware & 0,748 & 0,787 & 0,140 \\
\hline Organoware & 0,730 & 0,667 & 0,091 \\
\hline
\end{tabular}

\section{E. Technology Contribution Coefficient}

Based on the results of the calculation of the contribution of the component and the intensity of the component contributions can be obtained coefficient value the contribution of technology (technology contribution coefficient, TCC) of crude palm oil industry in Jambi Province are presented in Table 4.

TABLE IV

TEChNOlogy CONTRIBUTION COEFFICIENT OF CRUDE PALM OIL INDUSTRY IN JAMBI PROVINCE

\begin{tabular}{|c|c|}
\hline \multicolumn{2}{|c|}{ Technology Contribution Coefficient } \\
\hline $\begin{array}{c}\text { PT. SNP } \\
\text { BSP POM }\end{array}$ & $\begin{array}{c}\text { PSB II Bunut } \\
\text { PTPN VI POM }\end{array}$ \\
\hline 0.590 & 0.585 \\
\hline
\end{tabular}

TCC calculation results in FFB production process into CPO in Muaro Jambi Regency, Jambi Province on PT. SNP BSP POM and PSB II Bunut PTPN VI POM of 0.590 and 0.585 . This value indicates that the level of technology at both POM, is in good classification (based on interval TCC) 
and at the level of semi-modern technology (base on the level of technology).

According Hafids (2002), a portrait of the calculation results TCC contribution in forming technology value added of a product and also a portrait of the application of technology in the production process. The result of this calculation can be used as consideration for decision-making and policy formulation development.

\section{CONCLUSIONS}

Based on these results it can be concluded that: Value of TCC for CPO industry in Muaro Jambi Regency, Jambi Province on PT.SNP BSP POM and PSB II Bunut PTPN VI $P O M$ respectively are 0.590 and 0.585 . The value of TCC is a portrait that the level of technology in the palm oil industry in Jambi Province based on a qualitative assessment of TCC interval are in good classification and based on the level of technology is at the level of semi-modern technology.

Suggestions provided on the results of this study are: Need for increased contribution of component technology is still low (Humanware), so that the level of technology in the palm oil industry in the Jambi Province can be increased. Need for further research on the level of technology applied to the POM with different regency in the Jambi Province, so it can be compared to the level of technology between each area of the regency.

\section{REFERENCES}

[1] Alkadri, D.S. Riyadi, Muchdie, S. Sewoyo and F. Moehtadi, ed., Technology Management for Regional Development: Basic Concepts and Implications. Technology Policy Directorate for Regional Development Agency for the Assessment and Application of Technology, Indonesia: Jakarta, 1999.

[2] Directorate General of Estate Plantation. (2013) Palm Oil Production by Province in Indonesia. 2008-2012 Year.[Online].Available: http://www.pertanian.go.id/infoeksekutif/bun/BUNasem2012/Produk siKelapaSawit.pdf. Download: 30 November 2013.

[3] Estate Plantation Services of Jambi Province, The number and capacity of Palm Oil Mill (POM) in Jambi Province Plantation Services Jambi Province. Jambi. Indonesia: Jambi, 2013.

[4] Fauzan, A, "Evaluation of Technology Development Unit Dok BTPI Muara Angke Jakarta". B.Sc. thesis. Faculty of Fisheries and Marine Sciences. Bogor Agricultural University. Bogor. Indonesia. 2009

[5] Hafids, S., "Technology Contributions on Tempoyak Industry in Jambi Province". Agricultural Product Technology and Industry., vol 1, pp. 42-46, 2002.

[6] Hafids, S., "The Technology Contribution Analysis on Tangkit Pineapple Industry". Agricultural Product Technology and Industry vol 5, pp. 44-46, 2006.

[7] Kumaraswamy, M.M., E.V. Egmond, M. Rahman and O. Ugwu. "Technology Exchange through Relationally Integrated Joint Venture teams". Proc. International Symposium of the CIB W92 on Procurement Systems: Project Procurement for Infrastructure Construction 2004, India: Chennai p. 326-334.

[8] Nazaruddin, Technology Management, Graha Ilmu, Indonesia: Yogyakarta, 2008.

[9] Sa'id, E.G., Rachmayanti and M.Z. Muttaqin, Agribusiness Technology Management, Ghalia Indonesia, Indonesia: Jakarta, 2004.

[10] Sarono, E.G. Sa'id, O. Suparno, Suprihatin and U. Hasanudin, Evaluation of Technological Content of Wastewater Treatment of Palm Oil Mill in Lampung Province, Indonesia. EnvironmentAsia vol 7, pp.39-44, 2014. 